\title{
PRESENT STATUS AND FUTURE STRATEGY OF FORAGE DEVELOPMENT IN NEPAL
}

Banshi Sharma

\begin{abstract}
Livestock is an integral part of agricultural production system in Nepal. Animal feed have been one of the major production inputs drawing attention of the producers. There is excess green forage available during the monsoon period, but for the remaining six months, over the winter and spring, there is a lack of feed. In commercialized farming situations farmers compensate for shortages of forages with supplementation of expensive concentrate feeds. There are different cultivars of oats presently cultivated in Nepal. The winter crops oat is highly important to livestock raisers in Nepal. Oats are largely self-pollinated so farmers can save their own seed for several crops, provided that rogueing is carried out and the usual precautions are taken against mechanical contamination. Oat straw is good, palatable roughage and is also excellent bedding. With the introduction of multi-cut cultivars and new management technologies, the yield of fodder oats has gone up from 15-20 t/ ha 50-93 ha/ ha. Non-legumes and legumes cropping can increase the condition of soil. So that farmers can be benefitted in subsequent cropping. Cost of production of livestock and its product can be lower down with better feeding practices of forage crops round the year.
\end{abstract}

Key words: Fodder, forage, livestock, nutrition, strategy, technology

\section{BACKGROUND}

Livestock is an integral part of agricultural production system in Nepal. Animal feed have been one of the major production inputs drawing attention of the producers as it alone shares nearly 65-70 percent of the production cost of milk and meat from ruminants(Sharma, 2012).

In between 1960-1970, different farms for the development of livestock were established at various ecological zones of Nepal such as Pokhara, Chitlang, Jiri, Jumla, Panchasaykhola etc. Feeds and forage development program was also carried out as a part of farm's activities.

After the intervention of Department of Livestock Services (DLS), Livestock Development Project from 1980's forage cultivation and seed production activities had been popularly accepted by the farmers. Over 20 different forage crops are grown for seed production. Major species grown by the farmers are oat, vetch, berseem, stylo, molasses, mulato, joint-vetch etc. The domestic production of forage seeds meets only 66 percent of the total requirements. Current production of forage seed in Nepal is only 73 tons whereas the demand of farmers and government programs are very high (Tara, 2005).

\footnotetext{
${ }^{1}$ Chief, Livestock Development Officer, National Pasture and Animal Feed Centre, Harihar Bhawan, Nepal
} 
The major feed resources in Nepal are agricultural by-products and forage. Winter forage crops (oat, vetch, berseem and fodder pea) and perennial forage species (Napier, Stylo, Molasses, mulato etc.) on marginal lands are increasing each year. Till now, about 0.1 percent of the cultivated land brought under forage cultivation and over 4,000 ha of pasturelands have already been improved (Pande, 1994).

The genus Avena comprises about 70 species; a few are cultivated. Avena sativa $L$. is known as white oat. White oat and red oat (A. byzantine) is the main oats grown for fodder and grain. They are hexaploids and modern cultivars may contain genetic material from both species. For smallholders, assuring access to seed of improved cultivars is very important this involves producing seed of acceptable quality and marketing it so that it is within easy reach of farmers. Both species are hexaploids with 42 chromosomes $(6 n=42)$. Oat was found in 4000 years old remains of Egypt. Oats are a crop of Mediterranean origin; not as old as wheat and barley, but their domestication dates back to ancient times (Suttie and Raynolds, 2004).

Cultivation of oats (Avena sativa L.) in Nepal was started some 100 years ago by landlords in the Terai region in order to provide green fodder during the dry winter months for their elephants (Pariyar, 2006). Oat (Bundel 851) was imported from Jhansi India in the year 1990. The yield of fodder oats has gone up from 15-20 t/ha to 50-93 t/ha. For commercial dairy pocket areas, the oat cultivars Awapuni, Swan, Caraville, Charisma, Canadian and Kent are recommended up to an elevation of $1600 \mathrm{~m}$ asl. Oats + vetch is the best mixture for high yields and improved soil fertility ( Pariyar, 2002). Among the cultivated forage crops, oat is the main fodder crop that can fit with the existing mixed crop livestock farming systems in Terai and hill zones (Upreti, 2005).

After oat, Berseem (Trifolium alexandrinum) is the most promising fodder species which provides green fodder during November- March, It is a traditional cultivated fodder legume which is in cultivation practices on farm since over last 40 years in the sub tropical region of the country (Kandel , 2006).

On the average of three years, common vetch (Vicia sativa) produced forage maximum forage yield (5.4 t/ha) among four winter forage legumes from two cutting management practices, which is highly significant to one cutting management practices (Munakarmi , 2000).

Fodder pea is one of the important winter forage crop in Nepal. The demand for winter legume forage crop is very high. Grass pea with less toxic materials to livestock shall be good alternatives in harsh climatic areas.

Oat with vetch mixture is a promising means of increasing winter forage for dry winter season in the eastern hills ( Kshetri et. al, 1993). 


\section{INTRODUCTION}

Livestock rearing is more in mountain and high hills (Sharma, 2002). The contribution together with production of food (meat, milk, and eggs), fibre, hides/skins and transportation amounts to about $15 \%$ of GDP which is $31 \%$ of Agricultural GDP (LMP, 1993) and 51 per cent of this contribution is derived from the hills, 38 per cent form Terai and 9 per cent from the mountains (APP,1995). Livestock population, in relation to arable land and animals per person, are large by Asian standards, with approximately 7.2 million cattle, 5.2 million buffalo, 9.7 million goats, and 0.8 million sheep (MOAD, 2011/2012).

Livestock production is a very important industry both on a national scale and for farming families; yet animal productivity is constrained by lack of fodder. The estimated total fodder production in Nepal is 6.1 million tons TDN (Total Digestible Nutrients), only 64 per cent of the fodder required by livestock ( Pariyar,2004).

There is excess green forage available during the monsoon period, but for the remaining six months, over the winter and spring, there is a lack of feed. In commercialized farming situations farmers compensate for shortages of forages with supplementation of expensive concentrate feeds. As concentrates are expensive, animals are not fed to their requirement thus introducing costs without significantly increasing production. This has serious implications for competitiveness of the local products against imported products and for the sustainability of livestock production systems.

Leasehold Forestry and Livestock Programme (LFLP) is being implemented in 22 mid-hill districts. Its goal is to reduce the poverty of 44,300 household in mid-hills through the increased production of forest and livestock products. Under livestock development component, the program is designed to cover goat/forage production and development, livestock trainings \& services and livestock implementation support. This program provides appropriate seed and planting materials of Stylo, Molasses, Napier, Brachiaria and broom grass, to help develop the lease hold plots and increase the availability of green forage. Availability of forage has reduced the drudgery of women for the collection of fodder from the forest and other community land. Supplied fodder and grass seeds to the leasehold forestry groups, resulted in increased green coverage of the leasehold forestry plots. The vegetative ground cover in new sites is on an average only 32 percent, which increases to 50 percent after one full growing season and gradually expands to an almost full coverage of 90 percent in seven years old sites. The degree of satisfaction by both female and male is high on grasses and fodder seeds and Napier slip distribution. To use the fodder to boost the income of the leasehold groups and to reduce poverty, the program provides all eligible member households with two mature vaccinated and drenched female goats. The Program has distributed 65,880 she 
goats and 3,493 bucks. Average number of goats per household differs significantly from before program $(0.82 \mathrm{AU} / \mathrm{HH})$ to after program $(1.54 \mathrm{AU} / \mathrm{HH})$ and the quality of goats has been improved over time. The increment in goat number is by 90 percent. The average household income of households in the LFUGs has been increased by 71 percent.

\section{PRESENT STATUS OF FORAGE DEVELOPMENT IN NEPAL}

The estimated total production in Nepal is about 15 million tones of dry matter, 6.1 million tons of TDN and 0.68 million tons of Crude protein. Nationally, only meet about 70 percent of the fodder required by the livestock produced. Of the total land area of Nepal, 20 percent is crop land, 12 percent is grass land, 30 percent is forest, 5 percent is shrub-land and 25 percent has other users (Giri, 1990). Fodder from the 3.0 million ha of cropland contributes to 47 percent of the total available TDN. Fodder from 5.5 million ha of forest contributes 30 percent of the total available TDN. The total available TDN produced from 706 thousand ha of shrub land is 7 percent per year. Fodder from the 1.7 million ha of grassland is 5 percent of the available TDN, and almost 1.0 million ha of non-cultivated inclusion contribute 11 percent of the total available TDN.

Berseem, vetch, cowpea and oats known varieties have been cultivating in Nepalese soil from last 45 years. But many of them are not registered yet in the national system. The production of forage crops and their marketing has been limited due to non-registration. Registration of all varieties of oat, berseem, vetch and cow pea which have been farming in Nepal would be done. The combination of legumes and non-legumes forage is in 40:60 ratios. The best combination in mid hill is to be found out.

Livestock is the main source of organic manure required for maintaining the soil fertility. It provides nine million tons manure annually to three million hectares cultivated land through the use of feed from grazing land (19\%), crop by product (37\%), forest biomass (35\%), and secondary plant residues (9\%) in Nepal (Sherchand, 2001).

The forage seed mapping study (TLDP, 2002) estimated that a minimum 32,800 ha of land will have to be planted under perennial and annual forage crops to meet animal requirements.

Inadequate feed supply and poor nutrition during the dry winter months (December to April) is one of the biggest constraints to the promotion of livestock development in Nepal. The grazing lands except the alpine meadows are under heavy grazing pressure (Pariyar, 1993). The fact that ruminants are underfed has resulted in late maturity, high calf and adult mortality, poor lifetime performance, and infertility in cattle and buffaloes (Sherchand and Pradhan 1997). 
The area under oats in Nepal has been estimated to be 10,000 ha and the productivity of green fodder $12 \mathrm{t} / \mathrm{ha}$ in two cuts(Pariyar, 2005). The total area under oats is 15,600 hectares and 150,000 households are now cultivating oats (NPAFC, 2014). The area under berseem is estimated of 1,500 ha with 3,000 households are cultivating berseem (NPAFC, 2014). Fodder pea and vetch have been cultivated along with oat.

Among different oat cultivars maximum fodder production was obtained from Kamdhenu (5.2 Mt DM/ha) followed by Netra (5 Mt DM/ha), Omihi, 83INC19G3 and Kent (4.7 Mt DM/ha) in Dhaibung VDC in Rasuwa district (Rajbhandari et al, 2010).

Among cultivars, Kent proved to be the best producer of green forage (35.55 - $40.72 \mathrm{t} / \mathrm{ha}$ ) (Mandal and Premy, 2005). The average GM production from oat+ vetch in fertilizer application and zero fertilizer application was $41.4{ }_{-}+9.51 \mathrm{Mt} / \mathrm{ha}$ and $27.7+6.4 \mathrm{Mt} / \mathrm{ha}$ respectively (Pradhan, 2001).

The highest amount of green matter from oat + berseem and berseem(47.42 t/ha and 47.24 $t /$ ha respectively) was observed from on station a experiment, which was highly significant whereas on farm condition oat + berseem mixture yielded highest amount of green matter (33.2 t/ha) (Shivakoti,1996).

Fresh forage of swan and kent varieties yields ranged between 7-9 $\mathrm{t} / \mathrm{h}$ (low), 11-18 $\mathrm{t} / \mathrm{ha}$ (mid) and 19-22 t/ha (high). No significant differences in production were observed between the 2 varieties and different times of sowing within an altitude (Kshetri, et. al 1993).

This experiment aimed to investigate the green matter production of three different combination of oat and legumes at four levels of Nitrogen (NO, N40, N70 and N100). The average GM yields at $\mathrm{N} 70(70 \mathrm{~kg} \mathrm{~N} / \mathrm{ha}$ ) was $20.9 \mathrm{~T} / \mathrm{ha}$ i.e. 34 percent higher compared to that of NO level-control(Shrestha, 1991).

An experiment comprising four cutting heights $3,5,7$ or $9 \mathrm{~cm}$ of six cultivars (kent, swan, Amuri, Caraville, JH 810 and JH 822 ) of oat with three replications was conducted at Khumaltar (NPFRP) in F/Y 2046/47 under rain fed condition to assess forage production. There was no significant effect of cutting heights on green matter production (Pariyar et al, 1991).Major research issue is that the seed production of leguminous and nonleguminous is very limited quantity. The farmers do not know the exact time of cutting for more biomass.

Seed is easily produced, so farmers do not have to buy often and farmer sales have greatly accelerated the spread of improved cultivars. Oats are largely self-pollinated so farmers can save their own seed for several crops, provided that rogueing is carried out and the 
usual precautions are taken against mechanical contamination. Oat straw is good, palatable roughage and is also excellent bedding.

The Terai region has larger share of cropped land $(50 \%)$. In contrast, for grazing land, the mountain region accounts for the bulk of the grazing land. Rice and wheat (75\% and $57 \%)$ of the total respectively, are the main crops in the Terai which are major sources of crop residues for winter feeding.

Among the cultivated forage crops, oat is the main fodder crop that can fit with the existing mixed crop- livestock farming systems in Terai and hill zones. 23 cultivars of oats were selected for better hay production. The hay yield of cultivar Stempede (20.6 mt/ha) was significantly higher than the N264256.67 cultivar (14.4 mt/ha).

With the introduction of multi-cut cultivars and new management technologies, the yield of fodder oats has gone up from 15-20 t/ha - 50-93 ha/ha.

Oat seed is a source of income in many areas; oats can produce $2 \mathrm{t} / \mathrm{ha}$ seed after taking one cut for fodder.

Although Rajbhandary and Shah (1981) reported that livestock get the greenest matter from June - September and the quality of forage available during this period could be regarded as more or less adequate. Oats are grown by farmers up to about $4000 \mathrm{~m}$, although the economic fodder production level is about $1600 \mathrm{~m}$ on irrigated land.

The inadequate feed supply and poor nutrition during the dry winter season (December April) is one of the biggest constraints to the promotion of livestock development in Nepal. Since 1970's 30 fodder oat cultivars are evaluated in relation to their adaptation.

An initial trial was conducted to know the production performance of 10 cultivars of oat (Avena sativa) under rain fed condition at Parawanipur. The cultivars tested were 3412, Canadian, Kent, 323/02, Pakistani PDLV, Omihi, Bundel 1551, Swan (PAK) and Charisma. Canadian variety performed better in this trial. The tested cultivars (Kent, Canadian swan and cravilie) did not differ significantly for green forage production. Highest green fodder yield was obtained from Amouri(17t/ha) and lowest from Awapuni (11.34 t/ha). Amouri and swan have been found to be the most potential oat cultivars under rain-fed condition (Osti et. Al, 1997).

Oat should be sown within first week of December for greater green forage yield in the central Terai.

If $8-16 \mathrm{~kg}$ oat+ vetch green fodder can be made available / day during winter, over $33 \%$ reduction in the cost of concentrate can be achieved. 


\section{FUTURE POTENTIALS OF FORAGE DEVELOPMENT IN NEPAL}

Forage mission have been implemented in Nepal from last two years and it will go for next three years. It covers 40 districts of Terai and mid hills. The program is tied up with artificial insemination mission in cattle and buffalo. The number of improved calves born will increased and the balance feed to them have to supply from forage mission.

The coverage of extra forage crops in 45,000 Ha areas. The majority of forage crops are winter forage crops followed by perennial and summer forage crops. The deficit of $34 \%$ in feed and fodder can be achieved.

The practices of hay and silage making can be enhanced. So that forage of high quality can be achieved in lean period or dry period of the year. The irrigation facility of forage crops will be enhanced. Multi-cut variety of forage will give us more biomass for increasing number of livestock.

\section{CONCLUSIONS}

1. In some districts, the activities are successful. So, there is need of expansion of successful stories to other districts too. The project can implement the activities according to forage seed and agro-ecological zones and apply more appropriate technology, so that the deficit forage seeds can be produced and ultimately, feed deficit will be mitigated.

2. Similarly, forages when combined with other feed ingredients, concentrate rations or when value added by treating with urea or making urea molasses mineral block (UMMB), will be more nutritive and give better results. So, along with commercialization of livestock industry, there is need of commercialization in the field of fodder and pasture development also.

3. Similarly, forages when combined with other feed ingredients, concentrate rations or when value added by treating with urea or making urea molasses mineral block (UMMB), will be more nutritive and give better results. So, along with commercialization of livestock industry, there is need of commercialization in the field of animal feed production.

4. The most important and crucial part of commercialization of animal feed is recent technology which can be easily adapted by small scale farmers too. There is need of technology and concept development by which farmers would motivate towards commercialization for preservation of animal feeds/fodders for winter period. Also, they can motivate only in production of fodders and feeds and selling to livestock entrepreneurs.

5. Nawalparasi is the one of the most vulnerable district due to climate change in western development region. The fodder plants are there but the number is not sufficient for current livestock population. The fodder plants are more in 17 Village 
Development Committee (VDCs) of hilly areas. Therefore intensity of cropping can be increased and their wastage can be utilized for animal feed. New technology of complete ration shall be introduced and animal genetics resources awareness campaign shall be done. The mitigation majors can be made in collaboration with local Non Government Organization (NGO), local bodies and District Livestock Services Office (DLSO). The Regional Directorate of Livestock Services (RDLS) shall give guidelines and support to this effort. 70 percent of woman is involved in livestock keeping and gender issue shall be given high priority in hills too. The district was under Third Livestock Development Project (TLDP) and Community Livestock Development Project (CLDP) in the past. Therefore, production of milk and meat can be enhanced with environmental friendly livestock farming in this district.

6. For next three years $30,000 \mathrm{Ha}$ forage crops are cultivated in Nepal to cope with rising demand from commercial dairy pockets areas of Nepal.

Agriculture contributes 35 percent of GDP. 591 billion Nepalese Rs have been contributed by Agriculture sector in $F / Y 2070 / 2071$ BS. Of which, 155 billion rupees is from livestock sector. Two third of livestock economy have been spent for livestock feeding. Therefore, livestock can be fed efficiently round the year. Non-legumes and legumes cropping can increase the condition of soil. So that farmers can be benefitted in subsequent cropping. Cost of production of livestock and its product can be lower down with better feeding practices of forage crops.

\section{ACKNOWLEDGEMENT}

I would like to thank Prof. Dr. Naba Raj Devkota from AFU for his suggestions for writing this paper.

\section{REFERENCE}

Agriculture Prospective Planning (1995), Agriculture Project Services Centre, Singhdurbar/John Meller Associates, Washington DC, USA.

D. Pariyar (2002), Case study: oat + vetch utilization for milk production, Proceedings of the third National Animal Science Convention, Nepal Animal Science Association, Khumaltar, Lalitpur, August 27-28, 2000, pp 73-77.

D. Pariyar (2004), Exploration and evaluation of fodder oat (Avena sativa) cultivars to sustain livestock production in winter, Proceedings of the fourth National Conference on Science and Technology, RONAST, Baneshwor, Kathmandu, Nepal March 23-26, 2004, pp216-221.

Giri MK (1990). Fodder production in Nepal- A review, proceedings of the second livestock workshop on livestock an fisheries research in Nepal, Khumaltar, Lalitpur, 11-16 March, 1990, pp 42-52.

JM Suttie and SG Raynolds (2004), Fodder oats, a world overview edited by JM Suttie and SG Raynolds, FAO publication.

Kshetri BB, PB Chemjong and KP Dewan (1993). Oat forage production in the eastern hills of Nepal. Working paper N.. 93/42, Pakhribas Agricultural Centre, Pakhribas, Dhankuta, Nepal.

Kshetri BB, PB Chemjong and PP Rai (1993).Preliminary results of a study of winter forage ( Oat and combination of oat and vetch) production in the Koshi hills of Nepal. Working paper N.. 93/62, Pakhribas Agricultural Centre, Pakhribas, Dhankuta, Nepal. 
LFLP (2014). Leasehold Forestry and Livestock Programme. Project Completion Report.S Kathmandu.

LMP (1993): Livestock Master Plan. The livestock Sector Volume III, Asian Development Bank /ANZDECK / APROSC.

Mandal P and KP premy (2005). Research activities on fodder oat cultivation for household income generation in the eastern Terai region of Nepal. Proceedings of the Workshop on Fodder Oats, Fodder Technology Packages and Small Farm Income Generation, Kathmandu, Nepal, 8-11 March, pp 51-56.

MOAD, 2011/2012. Statistical information on Nepalese Agriculture. Agribusiness Promotion and Statistics Division, Singh Durbar, Kathmandu, Nepal.

Munakarmi PB, SM Pradhan, KK Shrestha and D. Pariyar(2000). Effect of cutting on seed production of winter legumes. Proceedings of the fourth National Workshop on Livestock and Fisheries Research in Nepal, Agriculture Research Station, Pakhribas ,Dhankuta, pp 88-90.

Osti NP, RS Mandal, D Pariyar and PB Munakarmi (1997), Study on production performance of oat cultivars under rainfed condition at Parawanipur, Proceedings of the second National Workshop on Livestock and Fisheries Research in Nepal, Khumaltar, Lalitpur, Nepal, 24-25 September, pp 69-71.

Pande, RS 1994. Opportunities for fodder and pasture development and promising species in Nepal, II National Conference on science and Technology. RONAST, 8-11 June 1994, Kathmandu.

Pariyar D (2005). Evaluation of oat germplasm in Nepal. Proceedings of the Workshop on Fodder Oats, Fodder Technology Packages and Small Farm Income Generation, Kathmandu, Nepal, 8-11 March, pp 8-14.

Pariyar D. (2002). Fodder oats in Nepal. Proceedings of the fifth meeting of the the Temperate Asia Pasture and Fodder Network(TAPAFON), RNR Research Centre Bajo,Wangdue, Bhutan, 30 April 4 May, 2002, pp 167-180.

Pariyar D., P. Mandal and MK shrestha (1991)- Effect of cutting heights on the green matter production of oats. Proceedings of the first National Animal Science Convention, Nepal Animal Science Association, Khumaltar, Lalitpur, Jan 14-15, 1991, pp 52-55.

Pradhan SM, Pariyar D., PB Munakarmi, RN Kandel and KK shrestha (2001)- Assessment of winter fodder and their mixture in dairy pockets. Proceedings of the fourth National Animal Science Convention, Nepal Animal Science Association, Khumaltar, Lalitpur, Nov 29 to Dec 1, 2000, pp 127-131.

Rajbhandary HB and Shah SG (1981), Trends and projections of livestock production in the hills of Nepal, MoA/ADC, Kathmandu.

Sharma B.,2002, Role of improved livestock farming for preserving natural resources and limits the impact of climate change, Agriculture and Environment, pp 72-75.

Sharma Banshi (2007), Livestock feed situation in Nepal and potential intervention strategies to alleviate feed deficit. Proceedings on tenth National Veterinary Conference of Nepal Veterinary Association (NVA), NVA, P.O.Box 11462, Tripureswor, Kathmandu pp 71-77

Sherchand L.,2001, Livestock and its relation to environment. Agriculture and environment, Communication issue. Ministry of Agriculture and Cooperatives, Singh Durbar, Kathmandu, Nepal. pp 52-57.

Shivakoti KP(1996). On station and on farm study of monoculture and mixed cropping of oat and Berseem on green matter production in easternTerai. Proceedings of the National Workshop on Livestock and Fisheries Research in Nepal, Khumaltar, Lalitpur, 7-9 May, 1996, pp 50-53. 
Shrestha RP(1991). Green matter production of oats and legume combinations at four levels of nitrogen under rainfed conditions. Proceedings of the first National Animal Science Convention, Nepal Animal Science Association, Khumaltar, Lalitpur, Jan 14-15, 1991, pp 27-30.

Shrestha SR, P Sapkota and RC Mahato (1994)- Study of oat production at farm condition. Nepalese Journal of Animal Science, Nepal Animal Science Association, Khumaltar, Lalitpur, 8((8):1-4.

Tara PC (2005), Fodder and pasture seed production for household income generation.

TLDP annual report, (2002). Published by Third Livestock Development Project (TLDP). Department of livestock services, Hariharbhawan, Lalitpur, Nepal.

Upreti CR (2005). Livestock feeding systems and the place of fodder oats in Nepalese systems. Proceedings of the Workshop on Fodder Oats, Fodder Technology Packages and Small Farm Income Generation, Kathmandu, Nepal, 8-11 March, pp 77-82.S 